during most of his time at the National Physical Laboratory. By his investigations into the thermal properties of materials and contributions to the science of refrigeration, he has established an international reputation. Twice he went to the Antipodes in charge of -scientific investigations : first to study the incidence of brownheart in apples during shipment from Australia, and later to make a survey of the transport of New Zealand lamb. Dr. Griffiths's scientific publications have included three books, "Methods of Measuring Temperature", "Pyrometers" and "Refrigeration Principles and Practice", and about a hundred papers, of which for a joint one dealing with the fundamentals of evaporation he was awarded the Moulton Medal of the Institution of Chemical Engineers. Dr. Griffiths has held offices in many scientific societies, and is still serving as president of the Institut International du Froid. He has been succeeded at the National Physical Laboratory by Dr. R. W. Powell, who has been a member of the Heat Section since 1924.

\section{British Association Secretaryship: Sir George Allen, C.B.E.}

Sir GEORGE ALLEN, formerly vice-chancellor of the University of Malaya, has been appointed secretary to the British Association for the Advancement of Science in succession to Mr. D. N. Lowe. Sir George was born in Donegal and educated at the Methodist College and The Queen's University, Belfast. At the University he graduated in medicine. After service with the R.A.M.C. in East Africa during 1917-20, he worked for six years as bacteriologist in the Medical Research Laboratory in Nairobi. He then returned to England for postgraduate work in pathology at Oxford and in London hospitals. In 1928 he was appointed bacteriologist in the Institute for Medical Research at Kuala Lumpur. Shortly afterwards he became principal of the King Edward VII College of Medicine in Singapore; he was also president of Raffles College in Singapore. He assisted the Commission on University Education in Malaya to prepare plans for the creation of a University by the fusion of these institutions, and was the natural choice as first vice-chancellor when the new University was established in 1949. In the three years of his vice-chancellorship Sir George Allen succeeded, with tact and administrative skill, in blending two independent institutions into a thriving entity which is now playing an increasingly important part in the life of South-East Asia. He brings to his new work in the British Association a scientific and medical background, an informed sympathy for experimental and field research and wide experience in education and administration.

\section{Element 99}

WITH the ever-increasing amount of effort being devoted to research in nuclear physics, it is perhaps no longer surprising to learn of the production of yet another artificial element-number 99 in the Periodic System (The Times, February 3, quoting a statement from the U.S. Atomic Energy Commission). It is well known that there are at least two routes by which new heavy elements may be formed, namely, by successive neutron capture in lighter elements, followed by beta-decay, and also by the nuclear interactions of 'heavy' ions such as ${ }^{12} \mathrm{C}^{6+},{ }^{14} \mathrm{~N}^{6+}$, ${ }^{10} \mathrm{O}^{6+}$, accelerated in cyclotrons and used to bombard suitable targets. Both these methods may have been employed; but only one mass assignment has been made, namely, $A=247$. The nucleus $99^{247}$ is understood to decay by alpha-particle emission with a half-life of a few minutes. Although this achievement is not unexpected, it reflects the greatest credit on Prof. G. T. Seaborg, of Berkeley, California, and his collaborators. It will be interesting to learn what name the discoverers will propose for the element. The chemical properties may be predicted with some certainty on the basis of Seaborg's actinide hypothesis, and if such properties are in fact observed, one may refer to the element temporarily as eka. holmium. The rare earth holmium was named after Stockholm. One wonders whether the discoverers of element 99 can find a name for it, based on a placename, which is anything like so euphonious.

\section{Effect of Germanium on the Transformation of White to Grey Tin}

The (normally) slow transition of the white, tetragonal form of tin to the grey, cubic modification at $13 \cdot 2^{\circ} \mathrm{C}$. is well known, as is the fact that inoculation with the grey allotrope accelerates the transformation. It is now shown in a paper by $R$. R. Rogers and J. F. Fydell, entitled "Effect of Germanium on the Transformation of White to Grey Tin" (Canadian Department of Mines and Technical Surveys, Mines Branch, Technical Paper No. 5; pp. 1. Ottawa : Queen's Printer, 1953; 25 cents), that inoculation with germanium is similarly effective in producing the grey form, the tin and germanium being immersed in a strong aqueous solution of calcium chloride acidified with hydrochloric acid to $p \mathrm{H} 1.5$ at a temperature of $-30^{\circ} \mathrm{C}$. Whereas the grey variety made its appearance only after 31 days with the 'pure' tin, 2 per cent of germanium caused its appearance after 4 days in the case of cast tin. It is noteworthy that in the case of hot-dipped tin coatings much longer periods are required than in the case of castings. The presence of germanium in the alloy, or in aqueous solution, has a corresponding accelerating effect. The presence of zine in the tin results in a marked retardation of the change, the zinc-free alloy containing 2 per cent of germanium first showing the grey tin after 0.9 day at $-40^{\circ} \mathrm{C}$. as compared with 14 days when 2 per cent of zinc is also present. This effect of germanium is possibly one reason for the well-known difference of different varieties of tin in the rate of transformation, since some tin ores are known to contain small amounts of that element.

\section{Fat from Fungi}

IF fats are to be produced by the industrial utilization of moulds, cheap carbon sources such as cellulose waste and molasses must be considered. As sucrose is the major constituent of molasses, the first stage in the relevant investigations is to ascertain the behaviour of different moulds towards it. S. Murray, M. Woodbine and T. K. Walker (J. Exp. Bot., 4, 11, 251; 1953) now report on the growth, development and fat formation of some forty-three strains of ten species of fungi when grown on different sucrose-containing media. The highest three yields of felt were given by Penicillium javanicum van Beyma, P. soppi Zaleski and Aspergillus nidulans Eidam, in that order. The fat content on felt weight was maximal at 34.8 per cent with $P$. soppi, at $28 \cdot 4$ per cent with Fusarium lini (i), and at $25 \cdot 8$ per cent with $A$. nidulans; on sugar 